\title{
The effect of climate and climate change on ammonia emissions in Europe
}

\author{
C. A. Skjøth ${ }^{1,2}$ and C. Geels ${ }^{2}$ \\ ${ }^{1}$ Department of Physical Geography and Ecosystems Science, Faculty of Science, Lund University, Lund, Sweden \\ ${ }^{2}$ Department of Environmental Science, Faculty of Science and Technology, Aarhus University, Roskilde, Denmark
}

Correspondence to: C. A. Skjøth (cas@dmu.dk)

Received: 25 June 2012 - Published in Atmos. Chem. Phys. Discuss.: 10 September 2012

Revised: 3 December 2012 - Accepted: 13 December 2012 - Published: 7 January 2013

\begin{abstract}
We present here a dynamical method for modelling temporal and geographical variations in ammonia emissions in regional-scale chemistry transport models (CTMs) and chemistry climate models (CCMs). The method is based on the meteorology in the models and gridded inventories. We use the dynamical method to investigate the spatiotemporal variability of ammonia emissions across part of Europe and study how these emissions are related to geographical and year-to-year variations in atmospheric temperature alone. For simplicity we focus on the emission from a storage facility related to a standard Danish pig stable with 1000 animals and display how emissions from this source would vary geographically throughout central and northern Europe and from year to year. In view of future climate changes, we also evaluate the potential future changes in emission by including temperature projections from an ensemble of climate models. The results point towards four overall issues. (1) Emissions can easily vary by $20 \%$ for different geographical locations within a country due to overall variations in climate. The largest uncertainties are seen for large countries such as the UK, Germany and France. (2) Annual variations in overall climate can at specific locations cause uncertainties in the range of $20 \%$. (3) Climate change may increase emissions by $0-40 \%$ in central to northern Europe. (4) Gradients in existing emission inventories that are seen between neighbour countries (e.g. between the UK and France) can be reduced by using a dynamical methodology for calculating emissions. Acting together these four factors can cause substantial uncertainties in emission. Emissions are generally considered among the largest uncertainties in the model calculations made with CTM and CCM models. Efforts to reduce uncertainties are therefore highly relevant.
\end{abstract}

It is therefore recommended that both CCMs and CTMs implement a dynamical methodology for simulating ammonia emissions in a similar way as for biogenic volatile organic compound (BVOCs) - a method that has been used for more than a decade in CTMs. Finally, the climate penalty on ammonia emissions should be taken into account at the policy level such as the NEC and IPPC directives.

\section{Introduction}

Ammonia plays an important role in many atmospheric processes. It is the main alkaline component in the atmosphere and is highly reactive either in forming aerosols (e.g. Seinfeld and Pandis, 2006) or by depositing rapidly to most surfaces including sensitive ecosystems (Sutton et al., 2007). Since it was recognised as an environmental pollutant, much effort has been put into understanding the fate of ammonia including the emission to the atmosphere and the following environmental effects (Sutton et al., 2008; Sutton et al., 2011). Sources of ammonia include wild animals (Sutton et al., 2000) ammonia-containing water areas (Barret, 1998; Sørensen et al., 2003), traffic (Kean et al., 2009), sewage systems (Reche et al., 2012), humans (Sutton et al., 2000) and agriculture. Here agriculture is considered the main source to emissions of ammonia globally (e.g. Bouwman et al., 1997) and regionally in e.g. Europe (Sutton et al., 2011) and USA (Pinder et al., 2004). Emissions of ammonia cause considerable concentrations near strong agricultural sources (Fowler et al., 1998; Geels et al., 2012; Hallsworth et al., 2010; Kryza et al., 2011), but the overall ammonia concentrations are quickly reduced to a low background level (de 
Leeuw et al., 2003), as ammonia is dispersed and incorporated into aerosols. These aerosols typically contribute $30 \%$ to $50 \%$ of the total aerosol mass of $\mathrm{PM}_{2.5}$ and $\mathrm{PM}_{10}$ (Anderson et al., 2003). Ammonia-containing aerosols are therefore a very important component in regional and global aerosols processes (Xu and Penner, 2012), as they may dominate the overall amount of aerosols in the $\mathrm{PM}_{2.5}$ and $\mathrm{PM}_{10}$ fractions. It has also been suggested that ammonia-containing aerosols are relevant for human health (Aneja et al., 2009), although the commentary by Sutton et al. (2011) highlights the high uncertainty on health effects that are related to ammonia emissions. Ammonia also contributes to the acidification and eutrophication of natural ecosystems leading to e.g. biodiversity changes and reduced plant species richness (Krupa, 2003; Stevens et al., 2010). More than $90 \%$ of the ammonia emitted in Europe originates from the agricultural sector (Reis et al., 2009). Here the main sources are livestock, manure management and application of fertilizer (Reis et al., 2009; Skjøth et al., 2011). Nearly all ammonia emissions are due to volatilization of ammonia from wet surfaces (Elzing and Monteny, 1997; Gyldenkærne et al., 2005). Volatilization of ammonia is a physical process that is highly temperature dependent (Gyldenkærne et al., 2005). The temperature in and above the emission sources such as manure spreading on the fields (Sommer et al., 2003) or buildings dynamically varies from hour to hour and throughout the season (Gyldenkærne et al., 2005). Due to this temperature effect of local meteorology, hot years are likely to give higher ammonia emissions compared to cold years. Similarly, hot days are likely to cause higher emissions than cold days. This temperature effect is according to a recent review by Menut and Bessagnet (2010) currently not taken into account by chemistry transport models (CTMs). This is also the case for chemistry climate models (CCMs). CTMs and CCMs could therefore be improved by including a dynamic description of the processes that cause the temporal variation in ammonia emissions (Gyldenkærne et al., 2005; Hellsten et al., 2007; Pinder et al., 2006; Skjøth et al., 2004; Skjøth et al., 2011).

State-of-the-art chemistry transport models such as DEHM (Brandt et al., 2012; Geels et al., 2012), EMEP (Simpson et al., 2012), TM5 (de Meij et al., 2006), CHIMERE (de Meij et al., 2009), MATCH (Langner et al., 2009; Langner et al., 2012) and LOTUS-EUROS (Barbu et al., 2009) rely on emissions from the EMEP system or similar sources with gridded emission inventories. These gridded emission inventories are often based on national emission factors combined with gridded activity data like e.g. animal numbers. For ammonia emission inventories, certain agricultural production methods or activities are related to specific emission rates that are obtained under specific climatic conditions within a country (Klimont and Brink, 2004). However, throughout even small countries like Denmark, certain areas have a warmer or colder climate compared to the mean across the country (Cappelen, 2011). Such spatial variations in climate will cause spatial variation in ammonia emission from otherwise identical sources. This climate effect due to temperature differences will likely be much more pronounced for larger countries like Germany, France and the UK as these countries have larger national variations in climate compared to Denmark or the Netherlands. To our knowledge, this spatial temperature effect has not previously been explored. It is therefore not known, whether this effect is important for $\mathrm{NH}_{3}$ emission models and the CTM models. But it is known that CTM models need accurate emission data and that the accuracy of the $\mathrm{NH}_{3}$ emissions is considered among the most important areas for improvement in relation to atmospheric chemistry and nitrogen compounds (Simpson et al., 2011). The effects of regional variation in climate on ammonia emissions therefore need to be explored, and the governing processes that cause these variations must be included in CTM and CCM models.

The effect of ammonia on climate has recently been discussed (de Vries et al., 2011; Erisman et al., 2011). This also includes model calculations of ammonium-containing aerosols (Xu and Penner, 2012). However, the impact of climate change on future ammonia emission was not studied, thus neglecting a potential feedback mechanism between the nitrogen cycle and climate change. Such feedback mechanisms in the climate system that involves the nitrogen cycle have, in a review by Arneth et al. (2010), been highlighted as a critical component for biosphere/atmosphere processes. According to Arneth et al. (2010), these effects remain to be studied by the climate models. Current climate models that are used in the IPCC report predict an increase in temperature in main agricultural sectors such as Europe and United States (IPCC, 2007). The predicted increases in temperature in these high-emitting regions vary from location to location. Future ammonia emissions from these high emitting regions can therefore be expected to increase due to the temperature alone. This effect can also be expected to vary from region to region. How much these increases affect the feedback mechanisms in the climate system is currently not known.

In this study we will investigate how much ammonia emissions can change geographically and annually in central and northern Europe due to variations in temperature alone. We will also investigate the potential effect of climate change on these ammonia emissions by using simulated surface temperatures from seven different climate models within the ENSEMBLES project. The tool for these investigations is a modified version of the open-source dynamical $\mathrm{NH}_{3}$ emission model by Skjøth et al. (2011) with a spatial coverage from central Sweden to northern Italy.

\section{Methodology}

Hourly $\mathrm{NH}_{3}$ emissions are simulated using the dynamic model in an identical model domain as in Skjøth et al. (2011). Here we study the years 2006-2010, 2046-2050 and 20862090 using a fixed set of emissions for the year 2007 from 
Skjøth et al. (2011) to study how meteorology from year to year can change both the amount and the temporal variation of ammonia emissions. Similarly, we also superimpose the climatic signal from climate models on the meteorological data to study the effect of climate change on ammonia emissions. Meteorological input data are gridded reanalysed fields for the years 2006-2010 and climate model simulations for the period 1961-2099. Additionally we isolate the climatic signal (geographically and temporally) by investigating the variations in emissions throughout Europe from a standard storage facility on a farm with 1000 pigs.

\subsection{Meteorological input data}

The emission model has in this study used an input of meteorological fields of 2-m air temperature and 10-m wind speed. The data are reanalysed meteorological data from the MM5 meteorological model (Grell et al., 1995) in an identical setup as in Skjøth et al. (2011) that provides 1-h temporal resolution and $16.67-\mathrm{km}$ spatial resolution of the meteorological fields. Here we use meteorological data for the years 2006-2010. The reanalysed meteorological data with 1-h resolution have also been used in combination with longterm trends in monthly mean temperatures obtained from the results in an ensemble of regional climate models. The input from the climate models is a gridded data set of monthly temperatures based on the ensemble mean from 11 scenarios run by eight different regional-scale climate models obtained from the ENSEMBLES project (http://ensemblesrt3.dmi.dk). These combined data from ENSEMBLES and the MM5 model were then used to construct an hourly temperature data set for the years 2046-2050 and 2086-2090 (Appendix Fig. A1) using the following the procedure. First, the results from the climate models were re-projected to match the $16.67-\mathrm{km}$ grid resolution of the meteorological data from the MM5 model. Then, a running mean was calculated for the climate model results. This running mean was calculated for each re-projected grid cell. The running means are calculated separately for each month (e.g. January 2011, January 2012, January 2013, etc.) to take into account seasonal trends in the results from the climate models. The result is a series of trends in 2-m temperatures, which vary between grid cells and vary throughout the season. The trends are then superimposed to the hourly gridded reanalysed meteorological data from the MM5 model. This procedure ensures that the long-term temperature trend from the climate model scenarios is kept for the entire period and that the variations in these trends throughout the seasons also are kept. Likewise, the method ensures that the detailed hourly and spatial variation given by the MM5 model is maintained (Appendix Fig. A1) and that the year to year variability seen over a 5-yr period also is included. Finally the procedure corrects any bias in the surface temperatures that are present in the climate model results. It is well known that bias correction of climate model data is needed before they can be used as input to e.g. impact models or vegetation models (Dosio and Paruolo, 2011). By using trends from the climate model data, we have assumed that the overall bias in the results from the climate models is the same throughout the simulation period.

\subsection{Simulations with the Dynamical Ammonia Emission Model}

The Dynamic Ammonia Emission Model uses 15 different emission functions to describe the temporal variations of different agricultural activities (Gyldenkærne et al., 2005; Skjøth et al., 2004, 2011). The emission model also uses an inventory of gridded $\mathrm{NH}_{3}$ emissions (e.g. EMEP, EDGAR or national inventories), in combination with information on agricultural activities. In the current setup the officially reported EMEP emissions on $50 \mathrm{~km} \times 50 \mathrm{~km}$ grid resolution have been redistributed directly into the applied model domain with a resolution of $16.67 \mathrm{~km} \times 16.67 \mathrm{~km}$. Afterwards the gridded totals have been divided into different agricultural categories that are present in the emission model. This distribution is obtained from Table 2 in Skjøth et al. (2011) as it provides the national split between the different categories. The final result is a gridded estimate for all 15 source categories. The Dynamic Ammonia Emission Model is then used to calculate a temporal variation of ammonia emissions for all 15 categories with 1-h temporal resolution. Each of these 15 categories requires a normalization factor (Skjøth et al., 2004) to ensure consistency with official annual emission values. This normalisation factor will vary between grid cells and from year to year, depending on actual meteorology (Skjøth et al., 2004). Warm years will have higher normalisation factors than colder years. Here we have calculated the mean normalisation factor for the years 2006-2010 for each grid cell and used this as a reference in all subsequent calculations. So for the years 2007, 2047, 2087, etc., we use the actual meteorology for that particular year (e.g. 2047) and then use the mean normalization factor for the period 2006-2010. This allows us to assess annual variations in total emissions due to climate alone for each grid cell (e.g. warm years will have increased emissions etc.). The advantage of this method is that it allows us to isolate the climate signal (temporally and spatially). Secondly, the updated model procedure simplifies the model calculations significantly as a full pre-calculation run is not needed. The reason is that the annual normalization factor is removed in order to allow for annual fluctuations in the total emission. In this study we use the well-studied Tange area in Denmark as the reference site in order to investigate the spatiotemporal variability in ammonia emissions. In Fig. 1 the ammonia emission from our standard storage facility located in the Tange area is displayed as a function of air temperature. We have here chosen our storage facility related to a pig farm with 1000 animals that uses the same production methods as in Denmark. The applied temperature dependence is described in more detail in Skjøth et al. (2004), but from Fig. 1 it can be seen that 


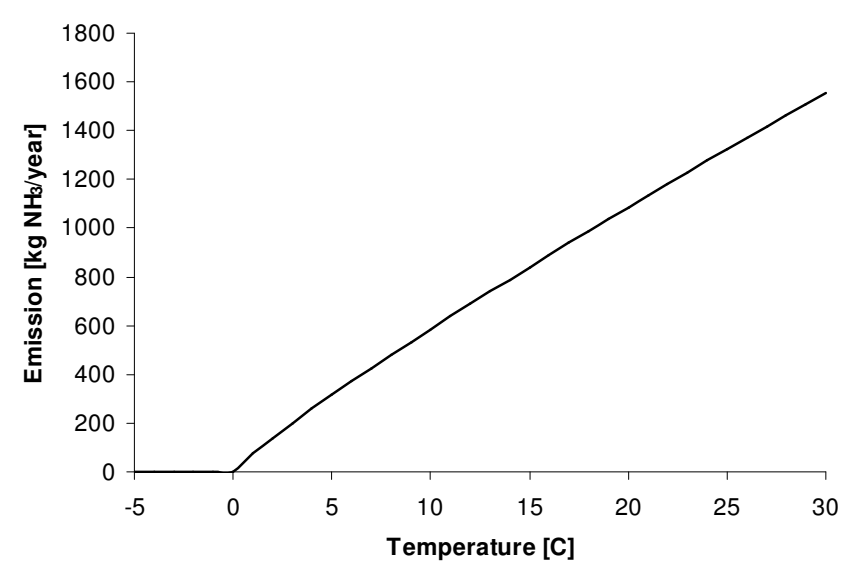

Fig. 1. Annual ammonia emission from storage facilities as function of temperature from a pig production facility with 1000 animals and production methods as in Denmark.

emission stops at $0{ }^{\circ} \mathrm{C}$ (due to freezing) and thereafter increases strongly with increasing temperatures.

The emission model is then used for two scenarios:

- scenario one: A scenario to investigate how much ammonia emissions can change geographically over central and northern Europe for the years 2007 and 2010 from a storage facility associated with a standard pig stable. For the storage facility at the Tange site in Denmark, this gives a mean annual emission of $480 \mathrm{~kg} \mathrm{NH}_{3}$ (Klimont and Brink, 2004).

- scenario two: A scenario on how much ammonia emissions may vary due to increasing temperatures under climate change by repeating the above calculations for the years 2047, 2050, 2087 and 2090, respectively.

\section{Results}

\subsection{Scenario one}

Figure 2 shows maps of gridded annual emission of $\mathrm{NH}_{3}$ from our test storage facility for the years 2007 and 2010 if it were placed at any location in the model domain and exposed to the local meteorology during the study years.

Figure 2a is the annual emission for the year 2007, which represents a relatively warm year in central Europe under current day conditions. Figure $2 \mathrm{~b}$ is the annual emission for the year 2010, which represents a relatively cold year under current day conditions. In both years, substantial geographic differences are seen in the emissions from our standard storage facility. These geographical differences in emissions are in the current setup entirely driven by differences in air temperature. One result is an overall north-south gradient with lowest emissions in the northern part of the domain and highest emissions in the most southern part of the domain. These
Table 1. National maximum and minimum annual ammonia emission from the standard pig storage facility from the gridded calculations. Note that minimum numbers for Austria, Italy and Switzerland should be treated with caution due to the dependency of the meteorological data set that was used in the calculations.

\begin{tabular}{l|cc|cc|cc}
\hline \multirow{2}{*}{} & \multicolumn{2}{|c|}{2007} & \multicolumn{2}{c|}{2047} & \multicolumn{2}{c}{2087} \\
\cline { 2 - 7 } & Min & Max & Min & Max & Min & Max \\
\hline Germany & 208 & 631 & 263 & 717 & 294 & 775 \\
Netherlands & 536 & 679 & 616 & 767 & 665 & 827 \\
Belgium & 455 & 633 & 539 & 718 & 587 & 773 \\
France & 224 & 750 & 283 & 840 & 317 & 900 \\
United Kingdom & 424 & 686 & 509 & 774 & 563 & 832 \\
Denmark & 485 & 610 & 564 & 696 & 613 & 753 \\
Sweden & 293 & 540 & 349 & 624 & 379 & 681 \\
Poland & 371 & 557 & 445 & 640 & 486 & 697 \\
Italy & 138 & 730 & 181 & 803 & 206 & 853 \\
Austria & 139 & 530 & 179 & 605 & 206 & 647 \\
Switzerland & 145 & 516 & 188 & 584 & 215 & 628 \\
Czech Republic & 368 & 522 & 444 & 598 & 485 & 642 \\
\hline
\end{tabular}

gradients are observed for both years, but vary in absolute amount between the years. An area of low emissions is in both years seen in the mountainous regions of the Alps in the southern part of the domain following the lower temperatures with altitude. Largest geographical differences in emissions are seen in the warm year of 2007, where our standard storage facility would have an annual emission of approx. $300 \mathrm{~kg} \mathrm{NH}_{3}-\mathrm{N} \mathrm{yr}^{-1}$ in southern Norway and up to 540 $620 \mathrm{~kg} \mathrm{NH}_{3}-\mathrm{N} \mathrm{yr}^{-1}$ in parts of the UK, Benelux, Germany, northern France and northern Italy. These emission rates are exceeded in smaller areas with a possible emission of 620 $700 \mathrm{~kg} \mathrm{NH}_{3}-\mathrm{N} \mathrm{yr}^{-1}$. Within a single country like Germany, a difference in emission from about 460 to $700 \mathrm{~kg} \mathrm{NH}_{3}-\mathrm{N} \mathrm{yr}^{-1}$ is seen. In the colder year of 2010, the standard storage facility would generally emit less throughout the entire domain, with only a few places where the emission from the storage facility could reach $540-620 \mathrm{~kg} \mathrm{NH}_{3}-\mathrm{N} \mathrm{yr}^{-1}$.

\subsection{Scenario two}

Figure 3a, b, c, and d show the annual emission for our standard storage facility for the year 2047, 2050, 2087, and 2090, respectively. They represent relatively cold (2050 and 2090) and warm (2047 and 2087) years under future conditions according to the applied ensemble of climate models. In Table 1 the maximum and minimum emission rates within the countries are given for the warm years 2007, 2047 and 2087, where we have excluded those grid cells in the alpine region that does not contain buildup and agricultural land by using the Corine Land Cover data set (European Commission, 2005). 

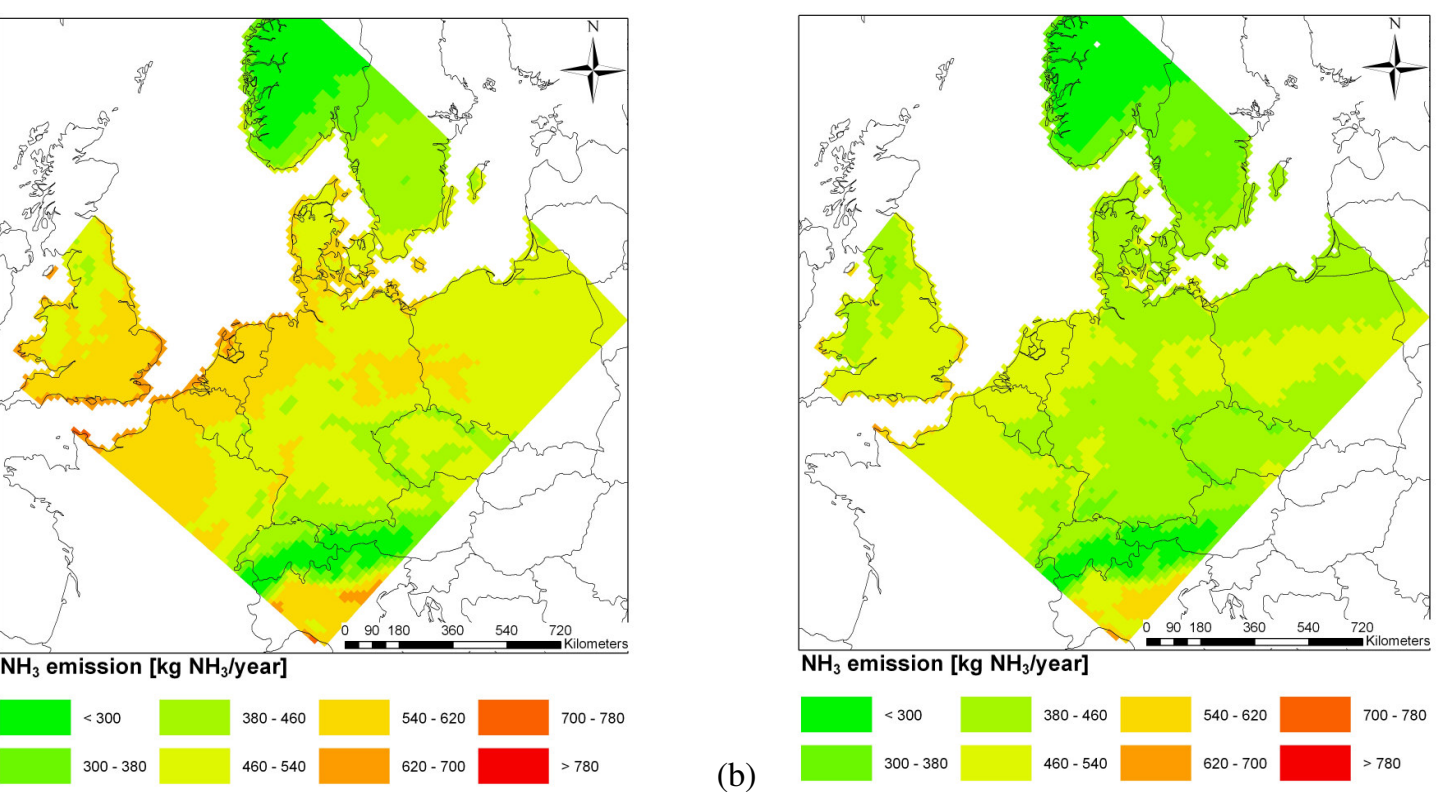

Fig. 2. Annual emission from storage facility in a pig farm with 1000 animals using average Danish production methods and exposed to different European climatic conditions in the years (a) 2007 and (b) 2010.

In all years substantial geographic differences are seen in the emissions. These differences are as in scenario one solely driven by geographical differences in air temperature. For all calculations a similar overall north-south gradient is seen in the emission pattern as for the years 2007 and 2010. Largest geographical differences are seen in the warm year of 2087, where our standard storage facility would have an emission rate of ca. $300-380 \mathrm{~kg} \mathrm{NH}_{3}-\mathrm{N} \mathrm{yr}^{-1}$ in southern Norway and up to $800-900 \mathrm{~kg} \mathrm{NH}_{3}-\mathrm{N} \mathrm{yr}^{-1}$ in parts of the UK, Benelux, Germany, northern France and northern Italy (Table 1). Large areas with a possible emission of $620-700 \mathrm{~kg} \mathrm{NH}_{3}-\mathrm{N} \mathrm{yr}^{-1}$ are also seen throughout Germany, Denmark, Poland and England. Within a single country such as Germany, a difference in emission from a minimum of about 294 to a maximum of $775 \mathrm{~kg} \mathrm{NH}_{3}-\mathrm{N} \mathrm{yr}^{-1}$ is seen in the warm year of 2087 .

In the colder year of 2050 , the standard storage facility would generally emit less throughout the domain, with only a few places where the emission from the storage facility could reach $620-700 \mathrm{~kg} \mathrm{NH}_{3}-\mathrm{N} \mathrm{yr}^{-1}$. A similar pattern in the emission rates is seen for the year 2090, although the areas with emissions in the range from 620-700 cover most of northern Italy, northern France and southern England.

\section{Discussion}

\subsection{Emission variations under present-day climate}

The model results show that if farmers use identical production methods, then meteorology and climate considerably affects the ammonia emission from this otherwise identical production. The model results (Fig. 2) for the historical years 2007 and 2010 are based on an input of reanalysed meteorological fields of air temperature to simulate emissions from this standard storage facility on a pig farm. The results show that the mountainous regions (Norway and the Alp region) and the eastern part of the model domain (Poland, Lithuania, Russia and Belarus) had almost the same or slightly lower emissions in 2010 compared with 2007. The central part includes England, the Netherlands, central and northern Germany and Denmark had between $15 \%$ and $25 \%$ higher emissions in 2007 compared to 2010. This difference is the variation that is seen between cold and warm years at a specific location. Likewise, the emission from a storage facility can change considerably depending on where it is located within a country, again due to gradients in the air temperature. This is of course more pronounced for large countries like Germany, where the emission from storage facilities within the country can change by as much as $40 \%$ alone due to differences in prevailing climate in different regions. Furthermore, mountain areas such as the alpine region also show large variations. Here it should be noted that this area is particular sensitive to the meteorological data set and that the chosen grid resolution might be too coarse for an accurate assessment in that region. In relation to official emission inventories such as those reported to EMEP or detailed national inventories (e.g. Velthof et al., 2012), this is an important result. In EMEP as well as in the more detailed national inventories, the total ammonia emission is a product of the number of animals and production methods by using emission factors for e.g. housing or storage facilities (Velthof et al., 2012). As such even the more advanced 
(a)
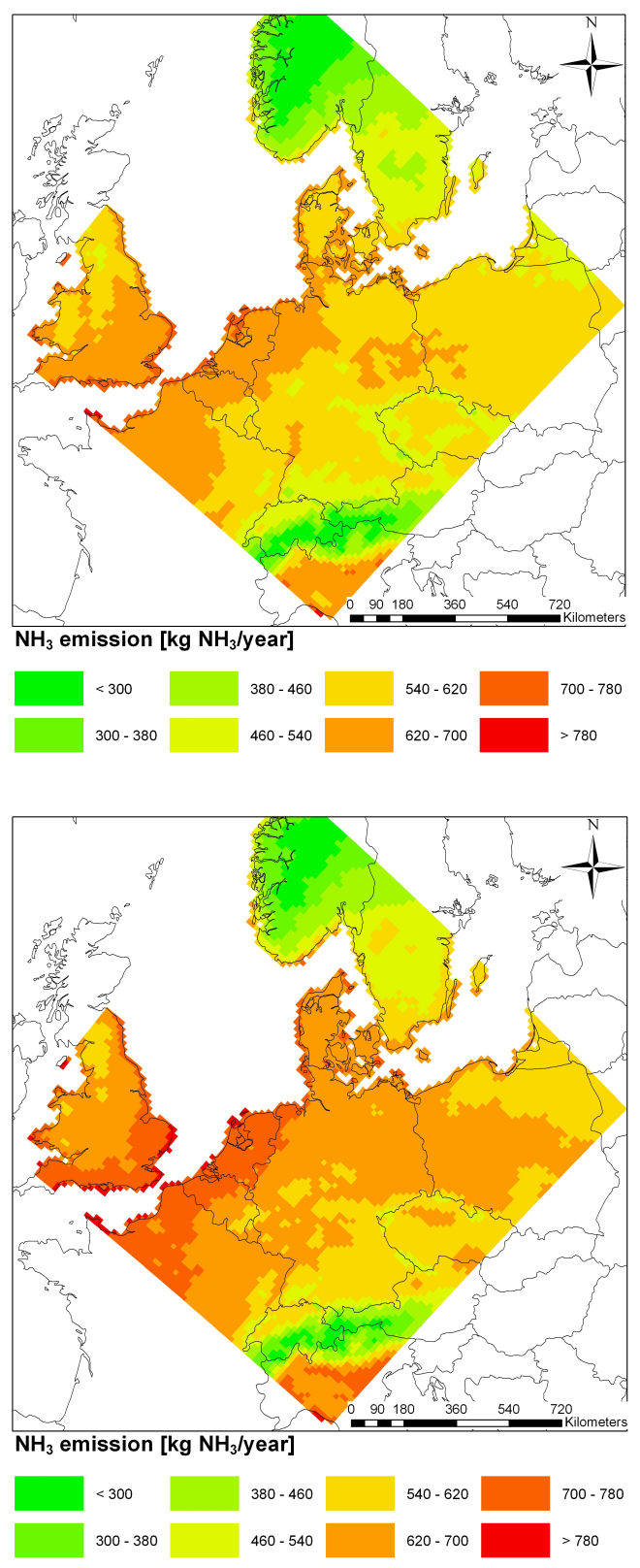

(b)
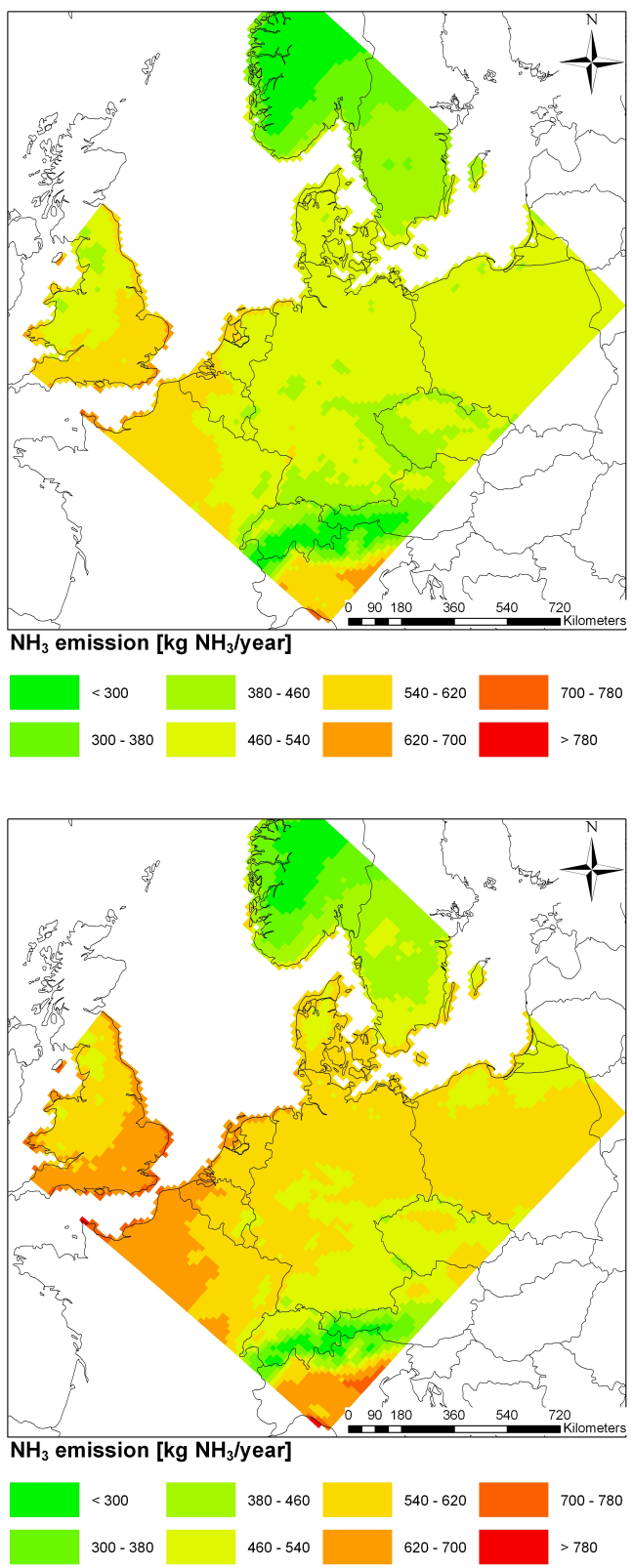

Fig. 3. Annual emission from storage facility in a pig farm with 1000 animals using average Danish production methods and exposed to different European climatic conditions in the years (a) 2047, (b) 2050, (c) 2087, (d) 2090, respectively

emission models do not fully take into account climate and climate variability as the overall concepts still rely on standard emission factors. These factors are applied in the model calculations, and often there is one national emission factor per country (e.g. Klimont and Brink, 2004) for each activity. These emission factors are then used for a number of years before they are updated. This is clearly shown by the differences in emission factors for the UK and France in Klimont and Brink (2004), where the emission factors are more than $50 \%$ larger for a storage facility in France compared to the UK. Graphically the methodology of relying on fixed emis- sion factors and numbers of animals can result in large gradients in emissions between the regions that are covered by statistics as seen in Fig. 5 by de Vries et al. (2011). Some of these gradients are due to variations in animal density, but the gradients are probably also due to model uncertainty. This uncertainty is not only due to the fact that statistical information like animal numbers is available only at a coarse scale, but also due to the fact that the entire emission inventory system relies on fixed emission factors that do not directly take into account meteorological variables (Beusen et al., 2008; Pouliot et al., 2012). The uncertainty related to the official 
Table 2. The main ammonia emission categories in Europe, an indication of their sensitivity to climatic variables as well as an overview of the contribution to the total emission from agricultural sources in Europe.

\begin{tabular}{|c|c|c|c|}
\hline Description & Climate sensitivity & Temporal emission pattern & $\begin{array}{l}\text { Fraction of European } \\
\text { Agricultural Emissions }\end{array}$ \\
\hline $\begin{array}{l}\text { Animal houses with forced } \\
\text { ventilation and heating }\end{array}$ & $\begin{array}{l}\text { Sensitive in warm regions, } \\
\text { less sensitive in cold regions }\end{array}$ & $\begin{array}{l}\text { Follows outside temperatures } \\
\text { to some degree }\end{array}$ & $34 \%-43 \%$ \\
\hline $\begin{array}{l}\text { Open animal houses with } \\
\text { natural ventilation }\end{array}$ & Sensitive & Follows outside temperatures & \\
\hline Storage facilities & Sensitive & Follows outside temperatures & \\
\hline Manure handling & Sensitive & $\begin{array}{l}\text { Follows outside temperatures } \\
\text { during application }\end{array}$ & $22 \%-26 \%$ \\
\hline Mineral fertilizer & Sensitive & $\begin{array}{l}\text { Follows outside temperatures } \\
\text { during application }\end{array}$ & $17 \%-26 \%$ \\
\hline Grazing animals & Sensitive & Follows outside temperatures & $6 \%-10 \%$ \\
\hline Other sources: emission from plants & Unknown & $\begin{array}{l}\text { Tightly connected to compensation } \\
\text { point and ambient } \mathrm{NH}_{3} \text { concentrations }\end{array}$ & $?$ \\
\hline Other sources: waste treatment & Not sensitive & & $2 \%$ \\
\hline Other sources: traffic & Not sensitive & & $2 \%$ \\
\hline Remaining other sources: e.g. industry & Not sensitive & & $3 \%$ \\
\hline Other sources: water areas & Unknown & $\begin{array}{l}\text { Depends on } \mathrm{NH}_{4}^{+} \text {concentration } \\
\text { in water and ambient } \mathrm{NH}_{3} \\
\text { concentrations }\end{array}$ & $?$ \\
\hline
\end{tabular}

* Numbers are based on calculations from the European Nitrogen Assessment, chapter 15 by DeVries et al. (2011) as well as sector-based emissions from EMEP extracted the 10th of May 2012.

gridded emission inventories varies considerably depending on geographical location. In general, the research on agricultural air quality is much behind in the US compared to in European countries like Denmark, the UK and the Netherlands (Zhang et al., 2008). In Denmark the uncertainty of the total annual emissions is assumed to be in the range of 5-10\% (Geels et al., 2012), while recent investigations for California in the US suggest that the uncertainty of ammonia emission exceeds a factor of ten (Nowak et al., 2012). According to EEA the overall European ammonia emissions from EMEP are estimated to be associated with an uncertainty of $\pm 30 \%$ (http://www.eea.europa.eu/data-and-maps/ indicators/eea-32-ammonia-nh3-emissions-1, accessed 14 November 2012). It is not clear if this estimate includes the effect of meteorological parameters, but most likely this uncertainty can be reduced by taking the meteorological factors into account (e.g. Zhang et al., 2008). As such, the uncertainties we here present will affect the results from CTM models as well as results from CCM models through atmospheric chemistry and aerosol processes such as radiation. How large the uncertainty is on a European or global scale and the associated effect on chemistry and climate are not known. The methods we have shown here are directly available for these types of models and will make it possible to assess this uncertainty. In Europe the emission of $\mathrm{NH}_{3}$ is regulated through the National Emission Ceiling directive (NEC 2001/81/EC), where the countries have agreed on legally binding emissions ceilings to be met in 2010. An evaluation made by the European Environment Agency in 2012 (Acid News 2012, No. 1, March 2012) shows that only two countries fail to meet the
$\mathrm{NH}_{3}$ directive limits. It is, however, expected that the current review of the EU policy will lead to stricter emissions ceilings in the future in order to improve the protection of the human health as well as the environment. For the evaluation of such international agreements, a harmonized emission reporting from the countries is crucial and the climatedependent uncertainty described in this paper complicates the evaluation of the $\mathrm{NH}_{3}$ ceiling. Furthermore the fact that a given agricultural activity will lead to larger emission in a warmer country or year than in a colder country/year, in spite of using identical production methods, could lead to a discussion on the fairness of the used approach with emissions ceilings. Our results indicate for example that the emissions from our test storage facility in 2010 in northwestern Europe were lower than in 2007. Thereby it would be easier for countries in this region to meet the ceiling for 2010.

\subsection{Emission variations under future climate}

The model results show that when climate and climate change projections are taken into account, the effect of temperature on ammonia emissions becomes even more pronounced. The results suggest that many areas can expect an increase in ammonia emissions from typical agricultural sources of up to $60 \%$ from the year 2010 . The increase varies from year to year and from location to location. The reason is that the results from the climate models show different temperature increases throughout central and northern Europe. This result is also important as CTM models and CCM models that are used to study short-lived climate 
forcers require accurate emissions. In the latest years there has been increased scientific focus on emissions from biogenic volatile organic compounds (BVOCs) as they are a precursor for short-lived climate forcers. Ammonia is the main alkalic component in the atmosphere and an important component in the formation of aerosols (Xu and Penner, 2012). An increase in surface temperatures will enhance ammonia emissions. This will affect the amount of aerosols causing a feedback in the climate system. Additionally the increased amount of atmospheric ammonia is likely to end up in terrestrial or marine ecosystems, thus affecting the $\mathrm{C}-\mathrm{N}$ cycle, which again is an important component of the climate system and a source to feedback mechanisms. To our knowledge, the importance of the feedback between increased temperatures and increased ammonia emission in relation to the climate system has not been previously studied. Again, the methods that are presented here can be implemented in CTM models as well as CCM models for climate change studies on atmospheric chemistry, radiation or the $\mathrm{C}-\mathrm{N}$ cycle.

\subsection{Overview of sensitivity of ammonia emissions in relation to increased temperatures and climate change}

In Europe, more than $90 \%$ of the total estimated ammonia emissions originate from agriculture. In Table 2 we give an overview of the different agricultural sources to ammonia and their sensitivity to climate. Also the fraction that the individual sources contribute to the total agricultural emission in Europe is given. This is done in order to illustrate the overall sensitivity of the European emissions to changes in climate. Between $34 \%$ and $43 \%$ are estimated to originate directly from buildings and storage facilities. The emissions from these source categories are all sensitive to climate and climate change, which is not taken into account in current emission estimates (e.g. Velthof et al., 2012). The same is true for manure handling, mineral fertilizer and grazing animals that contribute from $6 \%$ to $26 \%$ of the total emission. In some emission estimates the overall climate in a region is used to modify emission factors (e.g. Beusen et al., 2008). Management practice varies a lot across Europe, and future changes in this will have a huge impact on the ammonia emission. One example is the differences in handling the loading of the manure into the storage facility (e.g. top loading vs. bottom loading), which affects the overall emission rate (Muck and Steenhuis, 1982). But this does not justify the neglection of meteorology and climate on the emissions (e.g. Zhang et al., 2008). To our knowledge, a dynamic response on emissions from meteorology and climate is not taken into account as this requires a direct coupling to weather variables. The emission model we have used here has been shown to be able to describe seasonal as well as daily pattern of emission from a number of different agricultural activities (Geels et al., 2012; Gyldenkærne et al., 2005; Skjøth et al., 2004, 2011). Isolated studies on regional and local scale have shown that a main limitation of the model precision is the accuracy of the total emissions as well as the definition of the agricultural activities (Sommer et al., 2009). The simple redefinition of the activities from overall mean pattern into one of the 15 activity functions given by Gyldenkærne et al. (2005) has significantly improved the models results (Skjøth et al., 2004). It is well known that agricultural production methods vary considerably throughout Europe, such as the use of application methods of fertilizer during spring. The activities that are least affected by production methods and machinery are stables without heating and physical ventilation (typically cattle), storage facilities (pigs and cattle) and grazing animals (cattle, horses and sheep). However, grazing animals will typically be outside during summer and inside the stable systems during winter, which therefore again affects the emission pattern. These uncertainties only affect pig production to a small degree, as pigs are typically kept inside the buildings during the entire year in all the studied countries (Klimont and Brink, 2004). We have therefore chosen to study storage facility from a standard pig stable as this facility will have the most uniform emission pattern throughout central and northern Europe. A similar emission pattern can be found from cattle barns and storage facilities at cattle barns. But emissions from cattle barns are slightly more complicated to describe, as cattle are typically kept outside the building during a fraction of the year, which varies from country to country (Skjøth et al., 2011). Emissions from application of manure and mineral fertilizer are just as sensitive as emissions from buildings and storage facilities. However, there is a feedback mechanism in the climate system from that typical source. Farmers can change their application time due to overall change in climate. This can cause an increased growth period (e.g. due to warmer spring), a change in prevailing crops (e.g. from barley to sunflower in central and northern Europe) or a change in number of annual crop cycles (e.g. from one to two harvesting periods). Experiments with this kind of change have all been carried out by Danish farmers the last $10 \mathrm{yr}$ and they can all have a large impact on the emissions from manure and mineral fertilizer that have been applied to the fields. This as well as the previous studies by Skjøth et al. (2004) suggest that the key to accurate description of ammonia emissions is to connect the emission model with accurate mappings of agricultural activities such as types of production, use of fertilizer and number of animals.

\subsection{Relevance of including dynamical modelling of $\mathrm{NH}_{3}$ emissions in CCM and CTM models and current possibilities?}

The next generation of Earth system models such as ECEarth (http://ecearth.knmi.nl/) is now under development and used for studies that include feedback effects in the climate system (e.g. Bintanja et al., 2012). In EC-Earth this includes radiation, a chemistry model like TM5, an ecosystem model 
like LPJ-Guess, which also provides emissions of BVOCs for aerosol production. Our results suggest that Earth system models should also use a model that dynamically calculates ammonia emissions from humans, industry, traffic and agriculture as ammonia emissions are affected by climate. This will induce feedback effects on atmospheric chemistry and aerosols and hence backscattering as well as nitrogen deposition, which may both affect ecosystem behaviour (Sheppard et al., 2011). To our knowledge, all global models rely on fixed $\mathrm{NH}_{3}$ emission inventories such as those presented by Beusen et al. (2008). Dynamical models for ammonia emissions are currently not considered in global models such as Geos-Chem (e.g. Heald et al., 2012), although a number of authors have stated that the nitrogen issue is probably one of the biggest challenges humans will face in the future under an increased population load (Arneth et al., 2010; Gruber and Galloway, 2008; Sutton et al., 2011). Additionally, the effect of climate and ammonia emissions and potential feedback mechanisms has not been taken into account by the IPCC reports. Recent opinions by Erisman et al. (2011) do not take this effect into account, probably because the scientific understanding has not been available (e.g. Hertel et al., 2012). A scientific meeting in the Royal Society, 5-6 December 2011, on the global nitrogen cycle had an entire session dedicated to the ammonia issue. Here one of the recommendations was that the scientific community should put effort into a common vision on ammonia emission modelling for use by CTM and climate models (Sutton et al., 2012). Our results here suggest that the recommendation by Sutton et al. (2012) is highly relevant, and we propose that such model efforts should use an open source methodology to contribute towards this vision. Another important aspect is access to the relevant information on agricultural activities. In Europe, this information can potentially be obtained from modelling approaches that combine databases such as the Corine Land Cover2000 (European Commission, 2005) with the EUROFARM database (Neumann et al., 2009), while global-scale studies need more work, e.g. by combing existing inventories with data from FAO and detailed global land cover data. Despite of these complicating factors, the emission pattern is relatively stable with respect to two climatic factors: (1) Increased temperatures due to climate change will increase emissions from almost all typical agricultural sources; (2) regional climatic variations will change emissions from otherwise identical agricultural production facilities alone due to local variations in the prevailing climate.

\section{Conclusions}

Our study suggests that annual variations in meteorology, variations in overall climate between regions and climate change all affect the emission of ammonia substantially. The main reason is that volatilization of ammonia is very sensitive to air temperature. This effect is currently not taken into account neither in CTM models (Menut and Bessagnet, 2010) nor in climate model simulations. In fact, Menut and Bessagnet (2010) dedicate an entire subchapter to the ammonia issue in their review of CTM models that are used in forecasting of air quality. Similar results are obtained from a new model inter-comparison study by Pouliot et al. (2012). Menut and Bessagnet (2010) state that the temporal profile is not accurate enough in any of the European models, and Pouliet et al. (2012) state the temporal profile in ammonia is not correct in CTM models, which rely on fixed profiles. We therefore suggest that next generation of CTM models and especially CCM models take this feedback effect between emissions and climate into account by dynamically calculating ammonia emission within the models.

In relation to ozone and future air quality, the term "climate penalty" is often used, which means that stronger emission controls will be needed to meet a given future air quality standard (e.g. Jacob and Winner, 2009). Our results indicate that the same term can be used for ammonia as the projected change in climate alone will lead to increased emission of ammonia. This increased amount of ammonia will affect the known cascade of effects (Galloway et al., 2003) that are related to the nitrogen cycle. This includes effects on aerosols and radiation (e.g. Xu and Penner, 2012), effects on atmospheric chemistry (Seinfeld and Pandis, 2006), and effects on ecosystems (e.g. Sheppard et al., 2011) including possible feedback mechanisms. According to a recent article by Gruber and Galloway (2008), the feedback mechanisms in the climate systems that are related to the nitrogen cycle are poorly understood. In fact, a review by Arneth et al. (2010) claims that, despite the fact that nitrogen is a critical component of vegetation/atmosphere processes, nearly all possible feedback processes remain to be studied. This also includes increased ammonia emissions as in our study. This lack of consideration to feedback processes leads to substantial uncertainties (Gruber and Galloway, 2008). In relation to the NEC directive and a new emission ceiling for ammonia, it should for example be evaluated if the use of a specific target year is desirable. If the target year (currently 2010) is a year with above/below average temperatures in a given region, it will be harder/easier to meet the ceiling. In a future climate with a general warming trend and potentially more frequent extreme years, this issue will be even more relevant. The analysis and subsequent negotiations leading to a revised NEC directive should somehow include the climate sensitivity of $\mathrm{NH}_{3}$ emissions. The approach we have chosen here can be expanded to cover many different agricultural production methods and as such provide information to policy makers that addresses farming practice in relation to future ammonia emissions. 

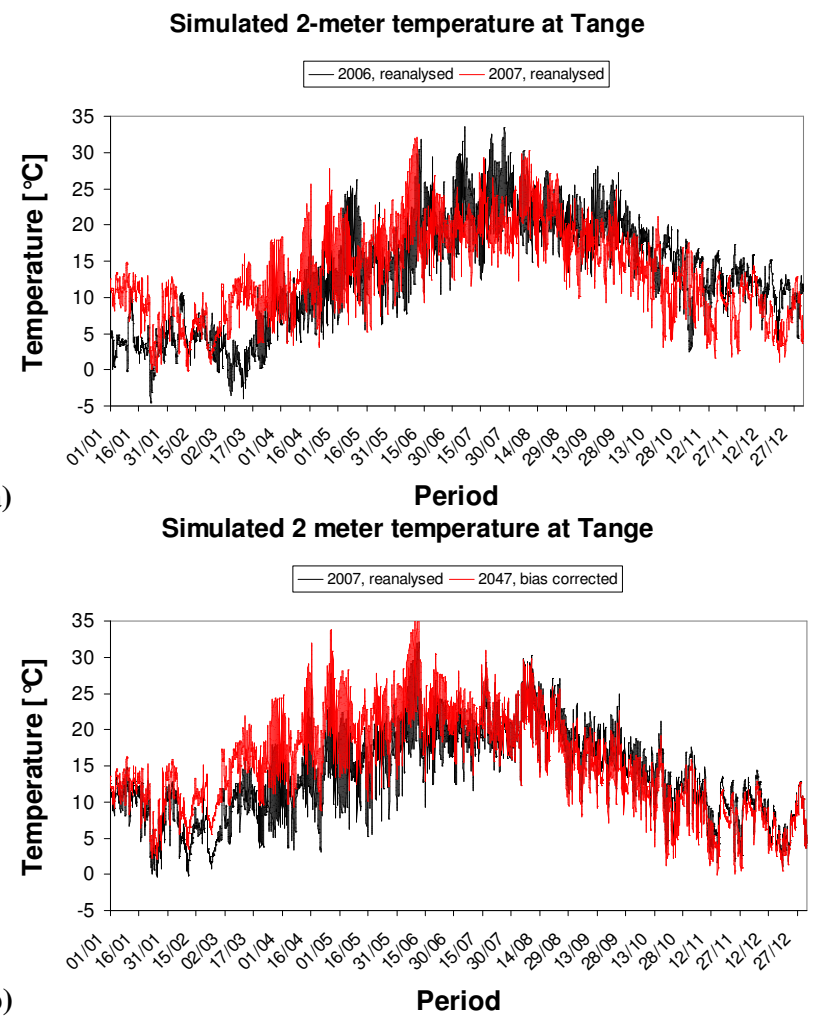

Fig. A1. (a) The hourly variation in simulated 2-m temperature for the Tange area that was used in the paper by Skjøth et al. (2011) and correspondingly hourly variations for the year 2006 using an identical model setup. (b) The hourly variation in simulated $2-\mathrm{m}$ temperature for the Tange area that was used in the paper by Skjøth et al. (2011) and the simulated future variation on 2-m temperature using climate model output from the ENSEMBLES data set and bias correction.

Acknowledgements. This study was supported by the EU project ECLAIRE (project no: 282910), the ECOCLIM project funded by the Danish Strategic Research Council and the Villum-Kann Rasmussen Foundation through a Post Doc grant to Carsten Ambelas Skjøth. The results presented here address two of the scientific challenges described in the FP7 project ECLAIRE (http://www.eclaire-fp7.eu/), specifically Work Package 6, on how to quantify ammonia emissions from agriculture in response to interactions of weather, climate and climate change.

Edited by: A. B. Guenther

\section{References}

Anderson, N., Strader, R., and Davidson, C.: Airborne reduced nitrogen: ammonia emissions from agriculture and other sources, Environ. Int., 29, 277-286, 2003.

Aneja, V. P., Schlesinger, W. H., and Erisman, J. W.: Effects of Agriculture upon the Air Quality and Climate: Research, Policy, and Regulations, Environ. Sci. Technol., 43, 4234-4240, 2009.

Arneth, A., Harrison, S. P., Zaehle, S., Tsigaridis, K., Menon, S., Bartlein, P. J., Feichter, J., Korhola, A., Kulmala, M., O’Donnell, D., Schurgers, G., Sorvari, S., and Vesala, T.: Terrestrial biogeochemical feedbacks in the climate system, Nature Geosci., 3, 525-532, 2010.

Barbu, A. L., Segers, A. J., Schaap, M., Heemink, A. W., and Builtjes, P. J. H.: A multi-component data assimilation experiment directed to sulphur dioxide and sulphate over Europe, Atmos. Environ., 43, 1622-1631, 2009.

Barret, K.: Oceanic ammonia emissions in Europe and their transboundary fluxes, Atmos. Environ., 32, 381-391, 1998.

Beusen, A. H. W., Bouwman, A. F., Heuberger, P. S. C., Van Drecht, G., and Van der Hoek, K. W.: Bottom-up uncertainty estimates of global ammonia emissions from global agricultural production systems, Atmos. Environ., 42, 6067-6077, 2008.

Bintanja, R., van der Linden, E. C., and Hazeleger, W., Boundary layer stability and Arctic climate change: a feedback study using EC-Earth, Clim. Dynam., 39, 2659-2673, doi:10.1007/s00382011-1272-1, 2012.

Bouwman, A. F., Lee, D. S., Asman, W. A. H., Dentener, F. J., Van der Hoek, K. W., and Olivier, J. G. J.: A global high-resolution emission inventory for ammonia, Global Bio. Chem. Cy., 11, 561-587, 1997.

Brandt, J., Silver, J., Frohn, L. M., Geels, C., Gross, A., Hansen, A. B., Hansen, K. M., Hedegaard, G. B., Skjøth, C. A., Villadsen, H., Zare, A., and Christensen, J. H.: An integrated model study for Europe and North America using the Danish Eulerian Hemispheric Model with focus on intercontinental transport of air pollution, Atmos. Environ., 53, 156-176, 2012.

Cappelen, J.: Monthly means and extremes 1961-1990 and 19812010 for air temperature, atmospheric pressure, hours of bright sunshine and precipitation - Denmark, The Faroe Islands and Greenland, 1-21, 2011.

de Leeuw, G., Skjøth, C. A., Hertel, O., Jickells, T., Spokes, L., Vignati, E., Frohn, L., Frydendall, J., Schulz, M., Tamm, S., Sørensen, L. L., and Kunz, G. J.: Deposition of nitrogen into the North Sea, Atmos. Environ., 37, Supplement 1, 145-165, 2003.

de Meij, A., Krol, M., Dentener, F., Vignati, E., Cuvelier, C., and Thunis, P.: The sensitivity of aerosol in Europe to two different emission inventories and temporal distribution of emissions, Atmos. Chem. Phys., 6, 4287-4309, doi:10.5194/acp-6-4287-2006, 2006.

de Meij, A., Thunis, P., Bessagnet, B., and Cuvelier, C.: The sensitivity of the CHIMERE model to emissions reduction scenarios on air quality in Northern Italy, Atmos. Environ., 43, 1897-1907, 2009.

de Vries, W., Kros, J., Reinds, G. J., and Butterbach-Bahl, K.: Quantifying impacts of nitrogen use in European agriculture on global warming potential, Curr. Op. Environ. Sustain., 3, 291302, 2011.

Dosio, A. and Paruolo, P.: Bias correction of the ENSEMBLES high-resolution climate change projections for use by impact 
models: Evaluation on the present climate, J. Geophys. Res.Atmos., 116, D16106, doi:10.1029/2011JD015934, 2011.

Elzing, A. and Monteny, G. J.: Ammonia emission in a scale model of a dairy-cow house, Trans. Asae, 40, 713-720, 1997.

Erisman, J. W., Galloway, J., Seitzinger, S., Bleeker, A., and Butterbach-Bahl, K.: Reactive nitrogen in the environment and its effect on climate change, Curr. Op. Environ. Sustain., 3, 281290, 2011.

European Commission: Image2000 and CLC2000 Products and Methods European Commission, Joint Research Center (DG JRC), Institute for Environment and Sustainability, Land Management Unit, 21020 Ispra (VA), Italy, 1-152, 2005.

Fowler, D., Pitcairn, C. E. R., Sutton, M. A., Flechard, C., Loubet, B., Coyle, M., and Munro, R.: The mass budget of atmospheric ammoina in woodland within $1 \mathrm{~km}$ of lifestock buildings, Environ. Pollut., 102, 343-348, 1998.

Galloway, J. N., Aber, J. D., Erisman, J. W., Seitzinger, S. P., Howarth, R. W., Cowling, E. B., and Cosby, B. J.: The nitrogen cascade, Bioscience, 53, 341-356, 2003.

Geels, C., Andersen, H. V., Ambelas Skjøth, C., Christensen, J. H., Ellermann, T., Løfstrøm, P., Gyldenkærne, S., Brandt, J., Hansen, K. M., Frohn, L. M., and Hertel, O.: Improved modelling of atmospheric ammonia over Denmark using the coupled modelling system DAMOS, Biogeosciences, 9, 2625-2647, doi:10.5194/bg-9-2625-2012, 2012.

Grell, G. A., Dudhia, J., and Stauffer, D. R.: A description of the fifth-generation Penn State NCAR Mesoscale Model (MM5), Mesoscale and Microscale Meteorology Division, National Center for Atmospheric Research, Boulder, Colorado, USA, 122, 122, 1995.

Gruber, N. and Galloway, J. N.: An Earth-system perspective of the global nitrogen cycle, Nature, 451, 293-296, 2008.

Gyldenkærne, S., Ambelas Skjøth, C., Hertel, O., and Ellermann, T.: A dynamical ammonia emission parameterization for use in air pollution models, J. Geophys. Res., 110, D07108, doi:10.1029/2004JD005459, 2005

Hallsworth, S., Dore, A. J., Bealey, W. J., Dragosits, U., Vieno, M., Hellsten, S., Tang, Y. S., and Sutton, M. A.: The role of indicator choice in quantifying the threat of atmospheric ammonia to the 'Natura 2000' network, Environ. Sci. Policy, 13, 671-687, 2010.

Heald, C. L., J. L. Collett Jr., Lee, T., Benedict, K. B., Schwandner, F. M., Li, Y., Clarisse, L., Hurtmans, D. R., Van Damme, M., Clerbaux, C., Coheur, P.-F., Philip, S., Martin, R. V., and Pye, H. O. T.: Atmospheric ammonia and particulate inorganic nitrogen over the United States, Atmos. Chem. Phys., 12, 10295-10312, doi:10.5194/acp-12-10295-2012, 2012.

Hellsten, S., Dragosits, U., Place, C. J., Misselbrook, T. H., Tang, Y. S., and Sutton, M. A.: Modelling Seasonal Dynamics from Temporal Variation in Agricultural Practices in the UK Ammonia Emission Inventory Acid Rain - Deposition to Recovery, edited by: Brimblecombe, P., Hara, H., Houle, D., and Novak, M., Springer Netherlands, 3-13, 2007.

Hertel, O., Skjøth, C. A., Reis, S., Bleeker, A., Harrison, R. M., Cape, J. N., Fowler, D., Skiba, U., Simpson, D., Jickells, T., Kulmala, M., Gyldenkærne, S., Sørensen, L. L., Erisman, J. W., and Sutton, M. A.: Governing processes for reactive nitrogen compounds in the European atmosphere, Biogeosciences, 9, 49214954, doi:10.5194/bg-9-4921-2012, 2012.
IPCC: Climate Change 2007: The Physical Science Basis. Contribution of Working Group I to the Fourth Assessment. Report of the Intergovernmental Panel on Climate Change, Cambridge University Press, Cambridge, United Kingdom and New York, NY, USA, 1-996, 2007.

Jacob, D. J. and Winner, D. A.: Effect of climate change on air quality, Atmos. Environ., 43, 51-63, 2009.

Kean, A. J., Littlejohn, D., Ban-Weiss, G. A., Harley, R. A., Kirchstetter, T. W., and Lunden, M. M., Trends in on-road vehicle emissions of ammonia, Atmos. Environ., 43, 1565-1570, 2009.

Klimont, Z. and Brink, C.: Modelling of Emissions of Air Pollutants and Greenhouse Gases from Agricultural Sources in Europe, International Institute for Applied Systems Analysis (IIASA), Laxenburg, Autria, 1-69, 2004.

Krupa, S. V.: Effects of atmospheric ammonia $\left(\mathrm{NH}_{3}\right)$ on terrestrial vegetation: a review, Environ. Pollut., 124, 179-221, 2003.

Kryza, M., Dore, A. J., Blas, M., and Sobik, M.: Modelling deposition and air concentration of reduced nitrogen in Poland and sensitivity to variability in annual meteorology, J. Environ. Manage., 92, 1225-1236, 2011.

Langner, J., Andersson, C., and Engardt, M.: Atmospheric input of nitrogen to the Baltic Sea basin: present situation, variability due to meteorology and impact of climate change, Boreal Environ. Res., 14, 226-237, 2009.

Langner, J., Engardt, M., Baklanov, A., Christensen, J. H., Gauss, M., Geels, C., Hedegaard, G. B., Nuterman, R., Simpson, D., Soares, J., Sofiev, M., Wind, P., and Zakey, A.: A multi-model study of impacts of climate change on surface ozone in Europe, Atmos. Chem. Phys., 12, 10423-10440, doi:10.5194/acp12-10423-2012, 2012.

Menut, L. and Bessagnet, B.: Atmospheric composition forecasting in Europe, Ann. Geophys., 28, 61-74, 2010, http://www.ann-geophys.net/28/61/2010/.

Muck, R. E. and Steenhuis, T. S.: Nitrogen Losses from Manure Storages, Agricult. Wastes, 4, 41-54, 1982.

Neumann, K., Elbersen, B. S., Verburg, P. H., Staritsky, I., PerezSoba, M., de Vries, W., and Rienks, W. A.: Modelling the spatial distribution of livestock in Europe, Landscape Ecol., 24, 12071222, 2009.

Pinder, R. W., Strader, R., Davidson, C. I., and Adams, P. J., A temporally and spatially resolved ammonia emission inventory for dairy cows in the United States, Atmos. Environ., 38, 3747-3756, 2004.

Pinder, R. W., Adams, P. J., Pandis, S. N., and Gilliland, A. B.: Temporally resolved ammonia emission inventories: Current estimates, evaluation tools, and measurement needs, J. Geophys. Res., 111, D16310, doi:10.1029/2005JD006603, 2006.

Pouliot, G., Pierce, T., Denier van der Gon, H., Schaap, M., Moran, M., and Nopmongcol, U.: Comparing emission inventories and model-ready emission datasets between Europe and North America for the AQMEII project, Atmos. Environ., 53, 4-14, 2012.

Reche, C., Pandolfi, M., Alastuey, A., Moreno, T., Amato, F., Ripoll, A., and Querol, X.: Urban $\mathrm{NH}_{3}$ levels and sources in a Mediterranean envionment, Atmos. Environ., 57, 153-164, 2012.

Reis, S., Pinder, R. W., Zhang, M., Lijie, G., and Sutton, M. A.: Reactive nitrogen in atmospheric emission inventories, Atmos. Chem. Phys., 9, 7657-7677, doi:10.5194/acp-9-7657-2009, 2009. 
Seinfeld, J. H. and Pandis, S. N.: Atmospheric Chemistry and Physics: From Air Pollution to Climate Change, John Wiley \& Sons Inc., New York, 1-1203, 2006.

Sheppard, L. J., Leith, I. D., Mizunuma, T., Neil Cape, J., Crossley, A., Leeson, S., Sutton, M. A., van Dijk, N., and Fowler, D.: Dry deposition of ammonia gas drives species change faster than wet deposition of ammonium ions: evidence from a long-term field manipulation, Global Change Biol., 17, 3589-3607, 2011.

Simpson, D., Aas, W., Bartnicki, J., Berge, H., Bleeker, A., Cuvelier, C., Dentener, F., Dore, T., Erisman, J. W., Fagerli, H., Flechard, C., Hertel, O., Van Jaarsveld, H., Jenkin, M. E., Schaap, M., Smeena, V. S., Thunis, P., Vautard, R., and Vieno, M., Chapter 14: Atmospheric transport and deposition of reactive nitrogen in Europe in: The European Nitrogen Assessment Sources, Effects and Policy Perspectives, edited by: Sutton, M., Howard, C. M., Erisman, J. W., Billen, G., Bleeker, A., Grennfelt, P., van Grinsven, H., and Grizzetti, B., Cambridge University Press, Cambridge, UK, 298-316, 2011.

Simpson, D., Benedictow, A., Berge, H., Bergström, R., Emberson, L. D., Fagerli, H., Flechard, C. R., Hayman, G. D., Gauss, M., Jonson, J. E., Jenkin, M. E., Nyíri, A., Richter, C., Semeena, V. S., Tsyro, S., Tuovinen, J.-P., Valdebenito, Á., and Wind, P.: The EMEP MSC-W chemical transport model - technical description, Atmos. Chem. Phys., 12, 7825-7865, doi:10.5194/acp-127825-2012, 2012.

Skjøth, C. A., Geels, C., Berge, H., Gyldenkærne, S., Fagerli, H., Ellermann, T., Frohn, L. M., Christensen, J., Hansen, K. M., Hansen, K., and Hertel, O.: Spatial and temporal variations in ammonia emissions - a freely accessible model code for Europe, Atmos. Chem. Phys., 11, 5221-5236, doi:10.5194/acp-11-52212011, 2011.

Skjøth, C. A., Hertel, O., Gyldenkærne, S., and Ellermann, T.: Implementing a dynamical ammonia emission parameterization in the large-scale air pollution model ACDEP, J. Geophys. Res., 109, D06306, doi:10.1029/2003JD003895, 2004.

Sommer, S. G., Genermont, S., Cellier, P., Hutchings, N. J., Olesen, J. E., and Morvan, T.: Processes controlling ammonia emission from livestock slurry in the field, Eur. J. Agron., 19, 465-486, 2003.

Sommer, S. G., Østergård, H. S., Løfstrøm, P., Andersen, H. V., and Jensen, L. S.: Validation of model calculation of ammonia deposition in the neighbourhood of a poultry farm using measured $\mathrm{NH}_{3}$ concentrations and $\mathrm{N}$ deposition, Atmos. Environ., 43, 915920, 2009.

Sørensen, L. L., Hertel, O., Skjøth, C. A., Lund, M., and Pedersen, B.: Fluxes of ammonia in the coastal marine boundary layer, Atmos. Environ., 37, S167-S177, 2003.

Stevens, C. J., Dupre, C., Dorland, E., Gaudnik, C., Gowing, D. J. G., Bleeker, A., Diekmann, M., Alard, D., Bobbink, R., Fowler, D., Corcket, E., Mountford, J. O., Vandvik, V., Aarrestad, P. A., Muller, S., and Dise, N. B.: Nitrogen deposition threatens species richness of grasslands across Europe, Environ. Pollut., 158, 2940-2945, 2010.
Sutton, M., Reis, S., Riddick, S., Dragosits, U., Nemitz, E., Theobald, M. R., Tang, S., Braban, C. F., Vieno, M., Dore, A. J., Mitchell, R. F., Wanless, S., Daunt, F., Fowler, D., Blackall, T., Milford, C., Flechard, C., Loubet, B., Massad, R. S., Cellier, P., Clarisse, L., van Damme, M., Ngadi, N., Clerbaux, C., Skjøth, C., Geels, C., Hertel, O., Wichink Kruit, R. J., Pinder, R. W., Bash, J. O., Walker, J. D., Simpson, D., Horvath, L., Misselbrook, T., Bleeker, A., Dentener, F., and de Vries, W.: Toward a Climate-Dependent Paradigm of Ammonia Emission \& Deposition, submitted to Proc. Roy. Soc., Part B, November 2012.

Sutton, M. A., Dragosits, U., Tang, Y. S., and Fowler, D.: Ammonia emissions from non-agricultural sources in the UK, Atmos. Environ., 34, 855-869, 2000.

Sutton, M. A., Nemitz, E., Erisman, J. W., Beier, C., Bahl, K. B., Cellier, P., de Vries, W., Cotrufo, F., Skiba, U., Di Marco, C., Jones, S., Laville, P., Soussana, J. F., Loubet, B., Twigg, M., Famulari, D., Whitehead, J., Gallagher, M. W., Neftel, A., Flechard, C. R., Herrmann, B., Calanca, P. L., Schjoerring, J. K., Daemmgen, U., Horvath, L., Tang, Y. S., Emmett, B. A., Tietema, A., Penuelas, J., Kesik, M., Brueggemann, N., Pilegaard, K., Vesala, T., Campbell, C. L., Olesen, J. E., Dragosits, U., Theobald, M. R., Levy, P., Mobbs, D. C., Milne, R., Viovy, N., Vuichard, N., Smith, J. U., Smith, P., Bergamaschi, P., Fowler, D., and Reis, S.: Challenges in quantifying biosphere-atmosphere exchange of nitrogen species, Environ. Pollut., 150, 125-139, 2007.

Sutton, M. A., Erisman, J. W., Dentener, F., and Möller, D.: Ammonia in the environment: From ancient times to the present, Environ. Pollut., 156, 583-604, 2008.

Sutton, M. A., Oenema, O., Erisman, J. W., Leip, A., van Grinsven, H., and Winiwarter, W.: Too much of a good thing, Nature, 472, 159-161, 2011.

Velthof, G. L., van Bruggen, C., Groenestein, C. M., de Haan, B. J., Hoogeveen, M. W., and Huijsmans, J. F. M.: A model for inventory of ammonia emissions from agriculture in the Netherlands, Atmos. Environ., 46, 248-255, 2012.

$\mathrm{Xu}$, L. and Penner, J. E.: Global simulations of nitrate and ammonium aerosols and their radiative effects, Atmos. Chem. Phys., 12, 9479-9504, doi:10.5194/acp-12-9479-2012, 2012.

Zhang, Y., Wu, S. Y., Krishnan, S., Wang, K., Queen, A., Aneja, V. P., and Arya, S. P., Modeling agricultural air quality: Current status, major challenges, and outlook, Atmos. Environ., 42, 32183237, 2008. 